\title{
Article \\ Bullying Victimization among In-School Adolescents in Ghana: Analysis of Prevalence and Correlates from the Global School-Based Health Survey
}

\author{
Richard Gyan Aboagye ${ }^{1}\left(\mathbb{D}\right.$, Abdul-Aziz Seidu ${ }^{2,3}{ }^{\circledR}$, John Elvis Hagan, Jr. ${ }^{4,5, *(\mathbb{C}}$, James Boadu Frimpong ${ }^{4}{ }^{(}$, \\ Joshua Okyere $^{2}{ }^{(D}$, Abdul Cadri ${ }^{6}{ }^{\oplus}$ and Bright Opoku Ahinkorah ${ }^{7} \mathbb{C}$
}

1 School of Public Health, University of Health and Allied Sciences, Ho PMB 31, Ghana; raboagye18@sph.uhas.edu.gh

2 Department of Population and Health, University of Cape Coast, Cape Coast PMB TF0494, Ghana; abdul-aziz.seidu@stu.ucc.edu.gh (A.-A.S.); joshuaokyere54@gmail.com (J.O.)

3 College of Public Health, Medical and Veterinary Services, James Cook University, Townsville, QSD 4811, Australia

4 Department of Health, Physical Education, and Recreation, University of Cape Coast, Cape Coast PMB TF0494, Ghana; frimpongboadujames@gmail.com

5 Neurocognition and Action-Biomechanics-Research Group, Faculty of Psychology and Sport Sciences, Bielefeld University, Postfach 1010 31, 33501 Bielefeld, Germany

check for updates

Citation: Aboagye, R.G.; Seidu, A.-A.; Hagan, J.E., Jr.; Frimpong, J.B.; Okyere, J.; Cadri, A.; Ahinkorah, B.O. Bullying Victimization among In-School Adolescents in Ghana: Analysis of Prevalence and Correlates from the Global School-Based Health Survey. Healthcare 2021, 9, 292. https://doi.org/10.3390/ healthcare 9030292

Academic Editors: Pedram Sendi, Janet McDonagh and Terrell L. Strayhorn

Received: 12 January 2021

Accepted: 4 March 2021

Published: 7 March 2021

Publisher's Note: MDPI stays neutral with regard to jurisdictional claims in published maps and institutional affiliations.

Copyright: (c) 2021 by the authors. Licensee MDPI, Basel, Switzerland. This article is an open access article distributed under the terms and conditions of the Creative Commons Attribution (CC BY) license (https:// creativecommons.org/licenses/by/ $4.0 /)$.
6 Department of Family Medicine, Faculty of Medicine, McGill University, Montreal, QC H3S 1Z1, Canada; abdul20c@yahoo.com

7 School of Public Health, Faculty of Health, University of Technology Sydney, Sydney, NSW 2007, Australia; brightahinkorah@gmail.com

* Correspondence: elvis.hagan@ucc.edu.gh

Abstract: (1) Background: Although bullying victimization is a phenomenon that is increasingly being recognized as a public health and mental health concern in many countries, research attention on this aspect of youth violence in low- and middle-income countries, especially sub-Saharan Africa, is minimal. The current study examined the national prevalence of bullying victimization and its correlates among in-school adolescents in Ghana. (2) Methods: A sample of 1342 in-school adolescents in Ghana (55.2\% males; $44.8 \%$ females) aged 12-18 was drawn from the 2012 Global School-based Health Survey (GSHS) for the analysis. Self-reported bullying victimization "during the last 30 days, on how many days were you bullied?" was used as the central criterion variable. Three-level analyses using descriptive, Pearson chi-square, and binary logistic regression were performed. Results of the regression analysis were presented as adjusted odds ratios (aOR) at 95\% confidence intervals (CIs), with a statistical significance pegged at $p<0.05$. (3) Results: Bullying victimization was prevalent among $41.3 \%$ of the in-school adolescents. Pattern of results indicates that adolescents in SHS 3 $[\mathrm{aOR}=0.34,95 \% \mathrm{CI}=0.25,0.47]$ and SHS $4[\mathrm{aOR}=0.30,95 \% \mathrm{CI}=0.21,0.44]$ were less likely to be victims of bullying. Adolescents who had sustained injury $[\mathrm{aOR}=2.11,95 \% \mathrm{CI}=1.63,2.73$ ] were more likely to be bullied compared to those who had not sustained any injury. The odds of bullying victimization were higher among adolescents who had engaged in physical fight $[\mathrm{aOR}=1.90,95 \% \mathrm{CI}$ $=1.42,2.25]$ and those who had been physically attacked $[\mathrm{aOR}=1.73,95 \% \mathrm{CI}=1.32,2.27]$. Similarly, adolescents who felt lonely were more likely to report being bullied $[\mathrm{aOR}=1.50,95 \% \mathrm{CI}=1.08,2.08$ ] as against those who did not feel lonely. Additionally, adolescents with a history of suicide attempts were more likely to be bullied $[\mathrm{aOR}=1.63,95 \% \mathrm{CI}=1.11,2.38]$ and those who used marijuana had higher odds of bullying victimization $[\mathrm{aOR}=3.36,95 \% \mathrm{CI}=1.10,10.24]$. (4) Conclusions: Current findings require the need for policy makers and school authorities in Ghana to design and implement policies and anti-bullying interventions (e.g., Social Emotional Learning (SEL), Emotive Behavioral Education (REBE), Marijuana Cessation Therapy (MCT)) focused on addressing behavioral issues, mental health and substance abuse among in-school adolescents. 
Keywords: bullying victimization; Ghana; global school-based health survey; in-school adolescents; REBE; social support; suicide ideation

\section{Background}

Bullying victimization is one of the major perennial behavioral acts that happen in the school setting [1-3]. As such, this aspect of youth violence among in-school adolescents continues to remain a public health issue in most countries around the world, especially for parents, school authorities, and mental health practitioners [2,4,5]. Bullying victimization is both direct or indirect behavioral acts where the perpetrator who is usually powerful abuses the victim verbally (i.e., insulting, teasing, threatening); physically (i.e., coercion, hitting, pushing, kicking, forceful possession of someone's belongings), or emotionally (i.e., social exclusion, peddling falsehood about someone) in a repeated fashion [6-9]. According to Vanderbilt and Augustyn [10], these increased risks happen not only to bullies and their victims, but also to bystanders or onlookers. Since its operationalization, bullying victimization through social science research has been associated with an array of adverse health and psychosocial outcomes [11-14]. These outcomes are not limited to internalizing problems including low self-esteem [15,16], heightened depression [2,17], increased anxiety [2], poor social skills [18,19], suicidal ideations [20] and poor physical health [21]. Additionally, several studies indicate that bullying victimization may cause long-term psychological and/or neurodevelopmental disorders including nightmares, worry, and sadness $[4,14,19,22]$. Moreover, victims of bullying tend to skip classes more often, perform poorly in academics, avoid school activities, increased substance use, and become truant at a point in time and later develop Learning Disabilities, and Attention Deficit/Hyperactivity Disorder (ADHD) [14,17,23-26]. Available studies on bullying victimization in low-and-middle-income countries (LMICs) such as Ghana [20], Mozambique [3], Nigeria [27], and Malawi [8] indicate that bullying victimization is still high among in-school adolescents, with socio-demographic (e.g., sex, age, economic status $[3,5,9,27-31]$ ) and behavioral characteristics (e.g., loneliness, physical fighting, sexual behaviors, substance use, truancy $[2,3,19,31,32])$ as its correlates.

Despite the negative short and long-term health and psychological implications of bullying victimization on in-school adolescents, the issue has received less research attention in Ghana, with just a few studies on the concept [20,33]. Our study builds on the study by Acquah, Wilson and Doku [20], which used the 2007 Global School-based Health Survey (GSHS) dataset by using the 2012 version and examined patterns and correlates for bullying among young adolescents in Ghana. Again, whereas the study by Baiden et al. [33] studied bullying victimization as a predictor of suicidal ideation and suicide attempt among adolescents in Ghana, our study focuses on bully victimization, not as a predictor but an outcome of interest. Besides, context-specific influences may differentiate the prevalence and patterns of bullying victimization experiences among adolescents and young adults [34]. Additionally, with many Ghanaian schools not adhering to existing anti-bullying policy, together with previously reported high prevalence of bullying victimization among adolescents, providing contextual updated empirical information on bullying victimization is warranted [35]. Essentially, research on bullying victimization among in-school adolescents in the Ghanaian context is scanty. In order to help with the reduction in the prevalence of bullying victimization in the school settings in Ghana, there is the need for more studies to be carried out to gain an in-depth understanding of the correlates of bullying victimization among Ghanaian in-school adolescents which will, in turn, direct public health actions.

Therefore, the current study examined the prevalence and correlates of bullying victimization among in-school adolescents in Ghana using the 2012 GSHS data. In achieving this objective and based on extant literature (e.g., [3,5,9,18-22]) from LMICs and particularly in Ghana (e.g., $[14,24])$ on bullying victimization, it was hypothesized that the prevalence 
rate of bullying victimization would relatively be high. It was further anticipated that bullying victimization among in school adolescents would vary as function of gender, grade level, injury status, whether having or not having physical fights, having or not having suicide attempts and being or not being lonely as well as using or not using a substance [11]. However, because of possible context-specific variations as noted in previous studies, no specific directions were stated regarding the aforementioned hypotheses. Findings from the study could help in the early identification, management, and formulation of anti-bullying policies in Ghanaian schools and also improve already instituted policies.

\section{Materials and Methods}

\subsection{Study Design, Source of Data, and Sampling Procedure}

The data for the study were obtained from the 2012 GSHS of Ghana. The survey was conducted among in-school adolescents from the World Health Organization (WHO) countries to ascertain the risk and protective factors of health risk behaviors. In Ghana, the survey was conducted with partnership from the Center for Disease Control and Prevention (CDC), Middle Tennessee University, WHO, and the Ghana Education Service (GES). A cross-sectional design was employed using a structured questionnaire to obtain data from adolescents. The questionnaire covered health risk behaviors such as alcohol and drug use, dietary behaviors, hygiene, mental health, physical activity, unintentional injury, sexual behavior, tobacco use, violence, and protective factors. A two-stage sampling method was used to recruit adolescents from twenty-five senior high schools in Ghana. At the initial stage, the study schools were selected with probability proportional to the school's enrolment size. At the last stage, classes within chosen schools were randomly selected and all eligible students were recruited to participate in the study. The ten regions (then) were grouped into three zones; South (Greater Accra, Central, Volta, Eastern), Central (Brong Ahafo, Ashanti, Western) and North (Northern, Upper East and Upper West). Twentyfive (25) schools were randomly selected from each zone making a total of seventy-five schools in all the three zones. In each of the selected school, all the classrooms were included in the sampling frame. All the students in the sampled classrooms were eligible to participate in the survey. However, only students aged 10 to 19 years were studied. The survey included students who were aged 10 to 19 years (period of adolescence), present at school on the day of data collection, and showed evidence of written informed consent (those aged 18 years and above), and written parental or guardian consent form and child assent form (those between 18 years). This sampling method ensured that every eligible student had an equal chance of being selected for inclusion in the study as well as the generalizability of the results to a larger population of in-school adolescents in Ghana. A total of 1984 adolescents from selected senior high schools completed the survey. The school, student, and overall response rates were $96 \%, 74 \%$, and $71 \%$, respectively. In the present study, a total of 1342 adolescents with complete cases of variables of interest were included in the final analysis. Using this criterion, 66 students who had no information on bullying victimization were excluded from the study. They constituted $4.77 \%$ of total number of students eligible for the study. The dataset used is freely available at https: //www.who.int/ncds/surveillance/gshs/ghanadataset/en/ (accessed on 6 October 2020). We relied on the "Strengthening the Reporting of Observational Studies in Epidemiology" (STROBE) statement writing the manuscript [36].

\subsection{Study Variables}

\subsubsection{Outcome Variable}

Bullying victimization was the dependent variable in the study. It was derived from the question "During the past 30 days, on how many days were you bullied?" The possible responses were $1=0$ days; $2=1$ or 2 days; $3=3$ to 5 days; $4=6$ to 9 days; $5=10$ to 19 days; $6=20$ to 29 days; and $7=$ All 30 days. For this study, the responses were dichotomized into "Yes" and "No". Adolescents who reported being bullied at least once during the past 30 days were categorized as "Yes" whilst their counterparts who were not bullied 
( $1=0$ days $)$ were grouped as "No". The categorization of the responses was informed by literature $[2,3]$.

\subsubsection{Explanatory Variables}

The explanatory variables used in the study were based on the associations established in previous literature (e.g., [3,37]) and most importantly, their availability in the GSHS dataset. The variables consisted of socio-demographic (age, sex, grade, and hunger), health risk behaviors (physical fighting, physical attack, injury, truancy, alcohol use, cigarette smoking, marijuana use, tobacco use, suicidal ideation, suicidal attempt, loneliness, anxiety, and bullied), and protective factors (peer support, close friends, parental or guardian supervision, parental or guardian bonding, and parental or guardian connectedness). The variables we studied have been validated and used in several previous studies $[2,3,8,31$, $33,37,38]$. The detailed description of the variables and the recoded responses have been shown in Table 1.

Table 1. Study Variables.

\begin{tabular}{ccc}
\hline Variables & Question & Response Options and Recoding \\
\hline Oullied & Outcome Variable & \\
\hline & $\begin{array}{c}\text { During the past } 30 \text { days, on how many days } \\
\text { were you bullied? }\end{array}$ & $\begin{array}{c}1=0 \text { days; } 2=1 \text { or } 2 \text { days; } 3=3 \text { to } 5 \text { days; } 4=6 \\
\text { to } 9 \text { days; } 5=10 \text { to } 19 \text { days } 6=20 \text { to } 29 \text { days; } \\
\text { and } 7=\text { All } 30 \text { days } \\
\text { (coded as } 1=\text { No; and } 2-7=\text { Yes) }\end{array}$ \\
\hline
\end{tabular}

Explanatory Variables

\section{Socio-Demographic Characteristics}

\begin{tabular}{|c|c|c|}
\hline Age & How old are you? & $\begin{array}{c}1=12,2=13,3=14,4=15,5=16,6=17,7= \\
18 \text { years }(\text { coded as } 11-14=0 ; 15-18=1)\end{array}$ \\
\hline Sex & What is your sex? & $1=$ male, $2=$ female $($ coded $2=0,1=$ male $)$ \\
\hline Grade & In what grade are you? & $1=\mathrm{SHS} 1,2=\mathrm{SHS} 2,3=\mathrm{SHS} 3,4=\mathrm{SHS} 4$ \\
\hline $\begin{array}{l}\text { Hunger (proxy of } \\
\text { socioeconomic status) }\end{array}$ & $\begin{array}{l}\text { During the past } 30 \text { days, how often did you go } \\
\text { hungry because there was not enough food in } \\
\text { your home? }\end{array}$ & $\begin{array}{c}1=\text { never, } 2=\text { Rarely, } 3=\text { sometimes, } 4=\text { most } \\
\text { of the times, } 5=\text { always } \\
(\text { coded } 1-3=\text { No; } 4-5=\text { Yes })\end{array}$ \\
\hline \multicolumn{3}{|c|}{ Psychosocial Environmental Factors } \\
\hline Tobacco use & $\begin{array}{c}\text { During the past } 30 \text { days, on how many days did } \\
\text { you use any other form of tobacco, such as } \\
\text { chewing tobacco leaves? }\end{array}$ & $\begin{array}{c}1=0 \text { days; to } 7=\text { All } 30 \text { days } \\
(\text { coded as } 1=\text { No; and } 2-7=\text { Yes) }\end{array}$ \\
\hline Alcohol use & $\begin{array}{l}\text { During the past } 30 \text { days, on how many days did } \\
\text { you have at least one drink containing alcohol? }\end{array}$ & $\begin{array}{c}1=0 \text { days; to } 7=\text { All } 30 \text { days } \\
\text { (coded as } 1=\text { No; and } 2-7=\text { Yes) }\end{array}$ \\
\hline Smoking & $\begin{array}{l}\text { During the past } 30 \text { days, how many days did } \\
\text { you smoke cigarette? }\end{array}$ & $\begin{array}{c}1=0 \text { days; to } 7=\text { All } 30 \text { days } \\
(\text { coded as } 1=\text { No; and } 2-7=\text { Yes })\end{array}$ \\
\hline Marijuana use & $\begin{array}{l}\text { During the past } 30 \text { days, how many times have } \\
\text { you used marijuana (also called weed, Jah, } \\
\text { Indian hemp, ahabammono, and ganja) }\end{array}$ & $\begin{array}{l}1=0 \text { times; to } 5=20 \text { or more times } \\
(\text { coded as } 1=\text { No; and } 2-5=\text { Yes })\end{array}$ \\
\hline Loneliness & $\begin{array}{l}\text { During the past } 12 \text { months, how often have you } \\
\text { felt lonely? }\end{array}$ & $\begin{array}{l}1=\text { never, } 2=\text { rarely, } 3=\text { sometimes, } 4=\text { most of } \\
\text { the time to } 5=\text { always (coded as } 1-3=\text { No; and } \\
4-5=\text { Yes) }\end{array}$ \\
\hline Anxiety & $\begin{array}{l}\text { During the past } 12 \text { months, how often have you } \\
\text { been so worried about something that you could } \\
\text { not sleep at night? }\end{array}$ & $\begin{array}{c}1=\text { never, } 2=\text { Rarely, } 3=\text { sometimes, } 4=\text { most } \\
\text { of the times, } 5=\text { always } \\
(\text { coded } 1-3=\text { No, } 4-5=\text { Yes })\end{array}$ \\
\hline Injury & $\begin{array}{l}\text { During the past } 12 \text { months, how many times } \\
\text { were you seriously injured? }\end{array}$ & $\begin{array}{c}1=0 \text { times; to } 8=12 \text { or more time }(\text { coded as } 1= \\
\text { No; and } 2-8=\text { Yes })\end{array}$ \\
\hline
\end{tabular}


Table 1. Cont.

\begin{tabular}{|c|c|c|}
\hline Variables & Question & Response Options and Recoding \\
\hline Truancy & $\begin{array}{l}\text { During the past } 30 \text { days, on how many days did } \\
\text { you miss classes or school without permission? }\end{array}$ & $\begin{array}{c}1=0 \text { days, } 2=1 \text { or } 2 \text { days, } 3=3 \text { to } 5 \text { days, } 4=6 \\
\text { to } 9 \text { days, } 5=10 \text { or more } \\
(\text { coded as } 1=\text { No; and } 2-5=\text { Yes) }\end{array}$ \\
\hline Suicidal ideation & $\begin{array}{l}\text { During the past } 12 \text { months, did you ever } \\
\text { seriously consider attempting suicide? }\end{array}$ & $\begin{array}{c}1=\text { yes, } 2=\text { no } \\
(\operatorname{coded} 2=\text { No; and } 1=\text { Yes })\end{array}$ \\
\hline Suicidal attempt & $\begin{array}{c}\text { During the past } 12 \text { months, how many times did } \\
\text { you actually attempt suicide? }\end{array}$ & $\begin{array}{c}1=0 \text { times; } 2=1 \text { time; } 3=2 \text { or } 3 \text { times; } 4=4 \text { or } \\
5 \text { times; and } 5=6 \text { or more times } \\
\text { (coded as } 1=\text { No; and } 2-5=\text { Yes) }\end{array}$ \\
\hline Fight & $\begin{array}{l}\text { During the past } 12 \text { months, how many times } \\
\text { were you in a physical fight? }\end{array}$ & $\begin{array}{l}1=0 \text { times; } 2=1 \text { time; } 3=2 \text { or } 3 \text { times; } 4=4 \text { or } \\
5 \text { times; } 5=7 \text { or } 7 \text { times; } 6=8 \text { or } 9 \text { times; } 7=10 \\
\text { or } 11 \text { times; and to } 8=12 \text { or more times } \\
\quad(\text { coded as } 1=\text { No; and } 2-8=\text { Yes) }\end{array}$ \\
\hline Injury & $\begin{array}{l}\text { During the past } 12 \text { months, how many times } \\
\text { were you seriously injured? }\end{array}$ & $\begin{array}{l}1=0 \text { times; } 2=1 \text { time; } 3=2 \text { or } 3 \text { times; } 4=4 \text { or } \\
5 \text { times; } 5=7 \text { or } 7 \text { times; } 6=8 \text { or } 9 \text { times; } 7=10 \\
\text { or } 11 \text { times; and to } 8=12 \text { or more times } \\
\quad(\text { coded as } 1=\text { No; and } 2-8=\text { Yes) }\end{array}$ \\
\hline Attacked & $\begin{array}{l}\text { During the past } 12 \text { months, how many times } \\
\text { were you physically attacked? }\end{array}$ & $\begin{array}{c}1=0 \text { times; } 2=1 \text { time; } 3=2 \text { or } 3 \text { times; } 4=4 \text { or } \\
5 \text { times; } 5=7 \text { or } 7 \text { times; } 6=8 \text { or } 9 \text { times; } 7=10 \\
\text { or } 11 \text { times; and to } 8=12 \text { or more times } \\
\quad(\text { coded as } 1=\text { No; and } 2-8=\text { Yes) }\end{array}$ \\
\hline Close friends & How many close friends do you have? & $\begin{array}{c}1=0 ; 2=1 ; 3=2 ; \text { and } 4=3 \text { or more } \\
(\text { coded as } 1=\text { No; and } 2-4=\text { Yes) }\end{array}$ \\
\hline Helpful(Peer support) & $\begin{array}{l}\text { During the past } 30 \text { days, how often were most of } \\
\text { the students in your school kind and helpful? }\end{array}$ & $\begin{array}{c}1=\text { never, } 2=\text { Rarely, } 3=\text { sometimes, } 4=\text { most } \\
\text { of the times, } 5=\text { always } \\
\text { (coded as } 1-3=\text { No; and } 4-5=\text { Yes) }\end{array}$ \\
\hline $\begin{array}{l}\text { Parents check homework } \\
\text { (parental supervision) }\end{array}$ & $\begin{array}{c}\text { During the past } 30 \text { days, how often did your } \\
\text { parents or guardians check to see if your } \\
\text { homework was done? }\end{array}$ & $\begin{array}{c}1=\text { never, } 2=\text { Rarely, } 3=\text { sometimes, } 4=\text { most } \\
\text { of the times, } 5=\text { always } \\
\text { (coded as } 1-3=\text { No; and } 4-5=\text { Yes) }\end{array}$ \\
\hline $\begin{array}{l}\text { Understand problems } \\
\text { (Parental Connectedness) }\end{array}$ & $\begin{array}{c}\text { During the past } 30 \text { days, how often did your } \\
\text { parents or guardians understand your problems } \\
\text { and worries? }\end{array}$ & $\begin{array}{c}1=\text { never, } 2=\text { Rarely, } 3=\text { sometimes, } 4=\text { most } \\
\text { of the times, } 5=\text { always } \\
\text { (coded as } 1-3=\text { No; and } 4-5=\text { Yes) }\end{array}$ \\
\hline $\begin{array}{l}\text { Know what adolescent do } \\
\text { free time (Parental or } \\
\text { guardian Bonding) }\end{array}$ & $\begin{array}{l}\text { During the past } 30 \text { days, how often did your } \\
\text { parents or guardians really know what you were } \\
\text { doing with your free time? }\end{array}$ & $\begin{array}{c}1=\text { never, } 2=\text { Rarely, } 3=\text { sometimes, } 4=\text { most } \\
\text { of the times, } 5=\text { always } \\
(\text { coded as } 1-3=\text { No; } \text { and } 4-5=\text { Yes })\end{array}$ \\
\hline $\begin{array}{l}\text { Parental or guardian respect } \\
\text { for Privacy }\end{array}$ & $\begin{array}{l}\text { During the past } 30 \text { days, how often did your } \\
\text { parents or guardians go through your things } \\
\text { without your approval? }\end{array}$ & $\begin{array}{c}1=\text { never, } 2=\text { Rarely, } 3=\text { sometimes, } 4=\text { most } \\
\text { of the times, } 5=\text { always } \\
(\text { coded as } 1-3=\text { No; } \text { and } 4-5=\text { Yes })\end{array}$ \\
\hline
\end{tabular}

\subsection{Statistical Analyses}

The data analysis was carried out using Stata software version 16.0 (Stata Corporation, College Station, TX, USA). Three levels of analyses consisting of descriptive, Pearson chi-square, and binary logistic regression were performed. Descriptively, frequencies, and percentages were used to present the prevalence of the categorical variables. Secondly, Pearson chi-square test was carried out to determine the association between bullying victimization (outcome variable) and explanatory variables. The variables that showed a significant association $(p<0.05)$ were further placed in the logistic regression. At the binary logistic regression analysis, three models were used. The first model (Model I) was built to determine the association between socio-demographic variables (sex, grade, and hunger) and bullying victimization that were significant at the chi-square analysis. The second model (Model II) was built to examine the association between socio-demographic variables and health risk behaviors. The last model (Model III) was fitted to determine the 
association between all the explanatory variables that established a significant association at the chi-square analysis and bullying victimization. The results of the regression analyses were presented as adjusted odds ratios (aOR) with their respective $95 \%$ confidence intervals (CIs). All the recoded variables and reference categories used were determined based on the review of pertinent literature [2,35,38]. A p-value of less than $5 \%$ was considered significant. We checked for multicollinearity with the Variance Inflation Factor (VIF). The result showed a mean, minimum, and maximum VIFs were 1.26, 1.04, and 1.62, respectively, indicating no evidence of multicollinearity.

\subsection{Ethical Issues}

Ethical requirements for the use of both minors and non-minors were adhered to during the survey. First, institutional permission for the conduct of the study was sought from the Ministry of Education and Heads of selected schools. Secondly, written informed consent was sought from students 18 years and above before inclusion in the study. For those below 18 years, written child assent and parental or guardian consent forms were obtained from each child before participating in the study. The adolescents anonymously and voluntarily completed the survey questionnaire.

\section{Results}

\subsection{Prevalence and Bivariate Analysis of Bullying Victimization among In-School Adolescents in Ghana}

Table 2 presents the prevalence and bivariate analysis of bullying victimization among in-school adolescents in Ghana. The prevalence of bullying victimization among in-school adolescents in Ghana was $41.3 \%$. We had significant differences in the experience of bullying victimization across sex, grade, ever went hungry, experience of injury, fight, attack, anxiety, loneliness, suicidal ideation, suicidal attempt, alcohol use, tobacco use, marijuana use, peer support and parental or guardian respect for privacy. All variables that showed significant differences had a $p$-value $<0.05$. Bullying victimization was more prevalent in females (44.3\%), adolescents in SHS 2 (54.2\%), in-school adolescents who ever went hungry (50.3\%), injured (55.1\%), engaged in fighting (60.8\%), attacked (56.3\%), felt anxious (51.6\%), felt lonely $(55.0 \%)$, had suicidal ideation (57.2\%), and attempted suicide $(61.7 \%)$. In the area of substance use, bullying victimization was prevalent among in-school adolescents who were current alcohol users (56.1\%), current tobacco users $(73.0 \%)$, current cigarette smoking (74.4\%), and current marijuana users (84.4\%). Additionally, bullying victimization was more prevalent among in-school adolescents with without peer support $(37.3 \%)$ and those with parental or guardian respect for privacy $(51.4 \%)$.

Table 2. Bivariate Analysis of the Proportion of Bullying Victimization among In-school Adolescents in Ghana.

\begin{tabular}{|c|c|c|c|c|}
\hline \multirow[b]{2}{*}{ Variable } & \multicolumn{2}{|c|}{$N=1342$} & \multirow{2}{*}{$\begin{array}{c}\text { Bullying Victimization } \\
\text { Yes }(41.3 \%)\end{array}$} & \multirow{2}{*}{$\begin{array}{l}\text { Chi-Square } \\
\chi^{2}(p \text {-Value })\end{array}$} \\
\hline & Frequency & Percentage & & \\
\hline Age & & & & $1.23(0.268)$ \\
\hline $12-14$ years & 38 & 2.8 & 50.0 & \\
\hline $15-18$ years & 1304 & 97.2 & 41.0 & \\
\hline Sex & & & & $3.98(0.046)$ \\
\hline Female & 601 & 44.8 & 44.3 & \\
\hline Male & 741 & 55.2 & 38.9 & \\
\hline Grade & & & & $85.98(<0.001)$ \\
\hline SHS 1 & 396 & 29.5 & 54.0 & \\
\hline SHS 2 & 253 & 18.8 & 54.2 & \\
\hline SHS 3 & 429 & 32.0 & 30.8 & \\
\hline SHS 4 & 264 & 19.7 & 26.9 & \\
\hline Ever went hungry & & & & $6.23(0.013)$ \\
\hline No & 1179 & 87.9 & 40.0 & \\
\hline Yes & 163 & 12.1 & 50.3 & \\
\hline Injury & & & & $112.92(<0.001)$ \\
\hline No & 651 & 48.5 & 26.4 & \\
\hline Yes & 691 & 51.5 & 55.1 & \\
\hline
\end{tabular}


Table 2. Cont.

\begin{tabular}{|c|c|c|c|c|}
\hline \multirow[b]{2}{*}{ Variable } & \multicolumn{2}{|c|}{$\mathrm{N}=1342$} & \multirow{2}{*}{$\begin{array}{c}\text { Bullying Victimization } \\
\text { Yes }(41.3 \%)\end{array}$} & \multirow{2}{*}{$\begin{array}{l}\text { Chi-Square } \\
\chi^{2}(p \text {-Value })\end{array}$} \\
\hline & Frequency & Percentage & & \\
\hline Engaged in fight & & & & $80.38(<0.001)$ \\
\hline No & 972 & 72.4 & 33.8 & \\
\hline Yes & 370 & 27.6 & 60.8 & \\
\hline Attacked & & & & $70.56(<0.001)$ \\
\hline No & 857 & 63.9 & 32.8 & \\
\hline Yes & 485 & 36.1 & 56.3 & \\
\hline Truant & & & & $1.81(0.179)$ \\
\hline No & 933 & 69.5 & 40.1 & \\
\hline Yes & 409 & 30.5 & 44.0 & \\
\hline Anxiety & & & & $9.51(0.002)$ \\
\hline No & 1156 & 86.1 & 39.6 & \\
\hline Yes & 186 & 13.9 & 51.6 & \\
\hline Loneliness & & & & $22.78(<0.001)$ \\
\hline No & 1100 & 82.0 & 38.3 & \\
\hline Yes & 242 & 18.0 & 55.0 & \\
\hline Suicidal ideation & & & & $25.77(<0.001)$ \\
\hline No & 1134 & 84.5 & 38.4 & \\
\hline Yes & 208 & 15.5 & 57.2 & \\
\hline Suicidal attempt & & & & $55.65(<0.001)$ \\
\hline No & 1081 & 80.6 & 36.4 & \\
\hline Yes & 261 & 19.4 & 61.7 & \\
\hline Current alcohol use & & & & $15.94(<0.001)$ \\
\hline No & 1187 & 88.5 & 39.3 & \\
\hline Yes & 155 & 11.5 & 56.1 & \\
\hline Current tobacco use & & & & $27.46(<0.001)$ \\
\hline No & 1279 & 95.3 & 39.7 & \\
\hline Yes & 63 & 4.7 & 73.0 & \\
\hline Current cigarette smoking & & & & $18.13(<0.001)$ \\
\hline No & 1303 & 97.1 & 40.3 & \\
\hline Yes & 39 & 2.9 & 74.4 & \\
\hline Current marijuana use & & & & $25.11(<0.001)$ \\
\hline No & 1310 & 97.6 & 40.2 & \\
\hline Yes & 32 & 2.4 & 84.4 & \\
\hline Close friends & & & & $3.16(0.076)$ \\
\hline No & 179 & 13.3 & 35.2 & \\
\hline Yes & 1163 & 86.7 & 42.2 & \\
\hline Peer support & & & & $4.79(0.029)$ \\
\hline No & 870 & 64.8 & 43.4 & \\
\hline Yes & 472 & 35.2 & 37.3 & \\
\hline $\begin{array}{l}\text { Parental or guardian } \\
\text { supervision }\end{array}$ & & & & $2.97(0.085)$ \\
\hline No & 776 & 57.8 & 39.3 & \\
\hline Yes & 266 & 42.2 & 44.0 & \\
\hline $\begin{array}{l}\text { Parental or guardian } \\
\text { connectedness }\end{array}$ & & & & $2.17(0.141)$ \\
\hline No & 731 & 54.5 & 43.1 & \\
\hline Yes & 611 & 45.5 & 39.1 & \\
\hline $\begin{array}{c}\text { Parental or guardian } \\
\text { bonding }\end{array}$ & & & & $0.11(0.741)$ \\
\hline No & 802 & 59.8 & 41.6 & \\
\hline Yes & 540 & 40.2 & 40.7 & \\
\hline $\begin{array}{l}\text { Parental or guardian } \\
\text { respect for privacy }\end{array}$ & & & & $10.67(0.001)$ \\
\hline No & 1130 & 84.2 & 39.4 & \\
\hline Yes & 212 & 15.8 & 51.4 & \\
\hline
\end{tabular}

Source: GSHS, 2012.

3.2. Multivariable Regression Analysis of Predictors of Bullying Victimization among In-School Adolescents in Ghana

Table 3 presents the results of the multivariable logistic regression. It was realized in the final model (Model III) that adolescents in SHS 3 and SHS 4 were less likely to be victims of bullying. Adolescents who had sustained injury were more likely to be bullied compared to those who had not sustained any injury. The odds of bullying victimization were higher among adolescents who had engaged in physical fight and those who had 
been physically attacked. Additionally, adolescents who felt lonely were more likely to report being bullied as against those who did not feel lonely. Additionally, adolescents with a history of suicide attempts were more likely to be bullied. Similarly, adolescents who used marijuana had higher odds of experiencing bullying victimization.

Table 3. Multivariable Analysis of Predictors of Bullying Victimization among In-school Adolescents in Ghana.

\begin{tabular}{|c|c|c|c|}
\hline \multirow[b]{2}{*}{ Variable } & \multicolumn{3}{|c|}{ Bullying Victimization } \\
\hline & $\begin{array}{c}\text { Model I } \\
\text { aOR [95\% CI] }\end{array}$ & $\begin{array}{c}\text { Model II } \\
\text { aOR [95\% CI] }\end{array}$ & $\begin{array}{c}\text { Model III } \\
\text { aOR [95\% CI] }\end{array}$ \\
\hline \multicolumn{4}{|l|}{ Sex } \\
\hline Female & Ref. & Ref. & Ref. \\
\hline Male & $0.78 *[0.62,0.97]$ & $0.80[0.63,1.03]$ & $0.82[0.64,1.05]$ \\
\hline \multicolumn{4}{|l|}{ Grade } \\
\hline SHS 1 & Ref. & Ref. & Ref. \\
\hline SHS 2 & $0.97[0.71,1.34]$ & $0.92[0.65,1.30]$ & $0.90[0.64,1.27]$ \\
\hline SHS 3 & $0.37^{* * *}[0.28,0.49]$ & $0.35^{* * *}[0.25,0.48]$ & $0.34 * * *[0.25,0.47]$ \\
\hline SHS 4 & $0.31^{* * *}[0.22,0.43]$ & $0.30^{* * *}[0.21,0.43]$ & $0.30 * * *[0.21,0.44]$ \\
\hline \multicolumn{4}{|c|}{ Ever went hungry } \\
\hline No & Ref. & Ref. & Ref. \\
\hline Yes & $1.63 *[1.15,2.29]$ & $1.41[0.96,2.06]$ & $1.39[0.95,2.03]$ \\
\hline \multicolumn{4}{|l|}{ Injury } \\
\hline No & & Ref. & Ref. \\
\hline Yes & & $2.12 * * *[1.64,2.74]$ & $2.11^{* * *}[1.63,2.73]$ \\
\hline \multicolumn{4}{|c|}{ Engaged in fight } \\
\hline No & & Ref. & Ref. \\
\hline Yes & & $1.92^{* * *}[1.45,2.56]$ & $1.90^{* * *}[1.42,2.52]$ \\
\hline \multicolumn{4}{|l|}{ Attacked } \\
\hline No & & Ref. & Ref. \\
\hline Yes & & $1.72^{* * *}[1.32,2.25]$ & $1.73^{* * *}[1.32,2.27]$ \\
\hline \multicolumn{4}{|l|}{ Anxiety } \\
\hline No & & Ref. & Ref. \\
\hline Yes & & $1.16[0.81,1.66]$ & $1.15[0.80,1.65]$ \\
\hline \multicolumn{4}{|l|}{ Loneliness } \\
\hline No & & Ref. & Ref. \\
\hline \multirow{2}{*}{\multicolumn{4}{|c|}{$\begin{array}{l}\text { res } \\
\text { Suicidal ideation }\end{array}$}} \\
\hline & & & \\
\hline No & & Ref. & Ref. \\
\hline Yes & & $0.93[0.62,1.40]$ & $0.94[0.62,1.41]$ \\
\hline \multicolumn{4}{|c|}{ Suicidal attempt } \\
\hline No & & Ref. & Ref. \\
\hline Yes & & $1.66 *[1.13,2.42]$ & $1.63 *[1.11,2.38]$ \\
\hline \multicolumn{4}{|c|}{ Current alcohol use } \\
\hline No & & Ref. & Ref. \\
\hline Yes & & $1.34[0.90,2.01]$ & $1.33[0.88,1.99]$ \\
\hline \multicolumn{4}{|c|}{ Current tobacco use } \\
\hline No & & Ref. & Ref. \\
\hline Yes & & $1.49[0.74,3.00]$ & $1.43[0.71,2.89]$ \\
\hline \multicolumn{4}{|c|}{ Current smoking } \\
\hline No & & Ref. & Ref. \\
\hline Yes & & $1.19[0.46,3.06]$ & $1.21[0.47,3.10]$ \\
\hline \multicolumn{4}{|c|}{ Current marijuana use } \\
\hline No & & Ref. & Ref. \\
\hline Yes & & $3.30 *[1.09,10.03]$ & $3.36 *[1.10,10.24]$ \\
\hline
\end{tabular}


Table 3. Cont.

\begin{tabular}{|c|c|c|c|}
\hline \multirow[b]{2}{*}{ Variable } & \multicolumn{3}{|c|}{ Bullying Victimization } \\
\hline & $\begin{array}{c}\text { Model I } \\
\text { aOR }[95 \% \text { CI] }\end{array}$ & $\begin{array}{c}\text { Model II } \\
\text { aOR [95\% CI] }\end{array}$ & $\begin{array}{c}\text { Model III } \\
\text { aOR [95\% CI] }\end{array}$ \\
\hline \multicolumn{4}{|l|}{ Peer support } \\
\hline No & & & Ref. \\
\hline Yes & & & $0.82[0.63,1.06]$ \\
\hline \multicolumn{4}{|c|}{$\begin{array}{l}\text { Parental or guardian } \\
\text { respect for privacy }\end{array}$} \\
\hline No & & & Ref. \\
\hline Yes & & & $1.20[0.85,1.68]$ \\
\hline $\mathrm{N}$ & 1342 & 1342 & 1342 \\
\hline Pseudo $\mathrm{R}^{2}$ & 0.0544 & 0.1633 & 0.1650 \\
\hline
\end{tabular}

\section{Discussion}

Drawing from a nationally representative dataset, that is, the 2012 GSHS data, the study examined the prevalence and correlates of bullying victimization in Ghana. As hypothesized in the current study, the prevalence of bullying victimization among inschool adolescents in Ghana (41.3\%) was relatively higher compared to what was found by Baiden et al. [33] (40\%) but lower than the $60 \%$ prevalence that was found by Acquah et al. [20]. The possible reason for the difference in the findings could be the different survey years and sample size as well as structural variations in school settings, communities, and cultures [2]. Overall, socio-demographic factors demonstrated some variations on their association with bullying victimization, though partly as hypothesized.

Specifically, increasing grade was associated with lower odds of being bullied among the in-school adolescents in Ghana. This association confirms previous studies that bullying victimization decreases with increasing educational grade [39-42]. A plausible reason for the observed association could be that those in senior levels (SHS 3 and 4) were more physically and psychologically developed to protect themselves from being bullied compared those in lower levels [39]. Additionally, Owusu et al. [35] hypothesized in their study that among senior high schools in Ghana, lower levels of bullying victimization among those in higher levels could be as a result of the older aged students in those levels. Hence, students in higher levels in educational grade especially in Ghana are regarded as "seniors" and sometimes perpetuators of bullying rather than being victims.

Again, adolescents who used marijuana had a higher likelihood of being bullied. A growing body of national and international research suggests that all types of bullying victimization create a proximal risk for substance misuse and/or abuse among adolescents [43]. Current finding is corroborated by several studies $[44,45]$ that showed that substance abuse among adolescents increases their odds of experiencing bullying victimization. Although literature is replete with findings that drug/substance abuse exacerbates the odds of being bullied as an adolescent, most of these studies focused mainly on tobacco and alcohol use (e.g., [20,44]). The association between marijuana use and bullying victimization could also be rooted in Lazarus' coping theory [46]. This theory postulates that adolescents may engage in risk health-compromising behaviors (e.g., marijuana use) as a coping response to the exposure of unbearable life stressors such as bullying victimization. Therefore, current finding that marijuana use increases the odds of bullying victimization sets the tone for future studies to further replicate this association.

Suicidal attempts have been shown to be significantly associated with bullying victimization $[47,48]$. Our study confirmed these earlier findings by showing that greater odds of being bullied occurred among in-school adolescents who reported attempted suicidal behaviors. This finding epitomizes that not only does the suicidal attempts predict bullying victimization; the reverse can be the case where bullying victimization exacerbates the tendency to attempt suicide. According to Opperman et al. [49], bullying victimization has 
a high potential to create a deep sense of not belonging and/or feelings of unwantedness which tends to increase the odds of attempting suicide. Moreover, bullying victimization exacerbates low self-esteem [50] and diminished self-worth [51], resulting in suicidal ideations and subsequent suicide attempts. Some scholars have argued that the concept of impulsivity may also explain why some in-school adolescents may engage in violent and other risk-taking behaviors; suicidal behaviors [52,53] and substance use [54] because of sensation seeking [33,55]. Although available literature has focused on bullying victimization as the predictor of suicidal attempts, our findings reveal that suicidal attempt also predicts the odds or likelihood for an adolescent in school to experience bullying victimization.

Physically attacked and being exposed to injury increased the likelihood for adolescents in schools to be bullied. This finding is supported by Acquah, Wilson and Doku [20] who also found that being physically attacked and being exposed to injury was associated with higher odds of bullying victimization. Although the direct pathway between physical attack, injury and bullying victimization remains unclear, our findings is explainable from the perspective that being repeatedly attacked physically in itself constitutes bullying and the concomitant injuries can be a precursor or consequence of bullying [9].

Other results show that being lonely increases the odds of being bullied. The finding is consistent with the results from Campbell [56] who found that feelings of hopelessness and loneliness was more likely to be reported by adolescents who have been victims of all kinds of bullying. Adolescence is a transitional phase of human life and therefore, adolescents yearn to belong and associate. However, when this is not achieved but rather replaced with loneliness, it subjects the adolescents to all forms of bullying that can even exacerbate the loneliness being faced [57].

\subsection{Strength and Limitations}

The use of a nationally representative dataset like the GSHS is a major strength for our study as it allows us to be able to generalize the findings to in-school adolescents in Ghana. Moreover, the survey questionnaire has been used and validated across different cultural settings. Notwithstanding, our study had some limitations. We relied on data from a cross-sectional survey and for that matter, only associations can be made; causality cannot be made. Secondly, the use of a secondary data limited our analysis only to variables that were available in the dataset. Additionally, bullying victimization was assessed using only one question "During the past 30 days, on how many days were you bullied?" Hence, this criterion may affect the accuracy and reliability of the findings. Additionally, since the survey was a self-reported one, it can be subjected to non-response bias and social desirability. Therefore, other key theoretical predictors such as the effects of bystanders could not be accounted for or included in our analysis. As such, our results should be interpreted in light of the aforementioned limitations.

\subsection{Practical Implications for School Health}

School-based anti-bullying programs should address the burden of bullying victimization at different grade levels to better mirror each sub-group level experiences. Other school-based interventions should take into account that among in-school adolescents, especially males, physical forms of bullying victimization (e.g., physical fights), being attacked, adolescents who demonstrate elements of loneliness, those with hunger related challenges, and exhibit potential suicide attempts. Policy makers (e.g., Ghana Education Service) in conjunction school authorities should effectively revitalize existing school-based anti-bullying interventions and potential new programs through appropriate curriculum planning to promote positive school climate. Programs such as regular anti-bullying screening of adolescents in schools to ensure prevention, identification and early management to reduce adverse impacts connected with academic (e.g., school dropouts) and health outcomes (e.g., mental and emotional disorders) are encouraged. Other interventions (e.g., Social Emotional Learning [SEL], Rational Emotive Behavioral Education [REBE], peer 
social network systems) should help strengthen in-school adolescents' resilience, improve their social environments, and foster positive youth development.

\section{Conclusions}

Current findings show that four in every ten in-school adolescents in Ghana had experienced bullying victimization in the past 30 days prior to the study. This finding further reiterates the earlier assertion that bullying victimization is quite pervasive among in-school adolescents in the country. Factors identified to be associated with bullying victimization were grade of the student, engaging in physical fights, being attacked physically, injury, loneliness, suicidal attempts, and current use of marijuana. There is the need for policy makers and school authorities in Ghana to design and implement policies and anti-bullying interventions focused on addressing behavioral issues, mental health and substance abuse that can results in bullying among in-school adolescents as cited earlier. Future school context-specific studies could investigate what other specific factors (e.g., student-teacher ratio, school density, teacher attributes) not captured in the current study might influence bullying victimization.

\section{Declarations}

Ethics Approval and Consent to Participate: The survey was conducted with strict adherence to ethical protocols. In various countries, institutional permission was sought from either the Ministry of Education or the Ministry of Health. All the ethical requirements from these institutions were strictly adhered to, especially, concerning the inclusion of minors in a study. At the school level, written informed consent was sought from the heads of various schools included in the study. For adolescents below 18 years, parental or guardian consent and child assent were sought from them before inclusion into the study. Additionally, written informed consent was obtained from those aged 18 years or older. The sampled students anonymously and voluntarily completed the survey questionnaire.

Author Contributions: Conception and design of study, R.G.A., B.O.A. and A.-A.S.; analysis and/or interpretation of data, R.G.A.; drafting the manuscript, R.G.A., A.-A.S., J.E.H., J.B.F.J., J.O., A.C. and B.O.A.; revising the manuscript critically for important intellectual content, R.G.A., A.-A.S., J.E.H., J.B.F.J., J.O., A.C. and B.O.A. All authors have read and agreed to the published version of the manuscript.

Funding: We sincerely thank Bielefeld University, Germany for providing financial support through the Open Access Publication Fund for the article processing charge.

Institutional Review Board Statement: The study was conducted according to the guidelines of the Declaration of Helsinki, and did not require ethical approval.

Informed Consent Statement: Not applicable.

Data Availability Statement: Publicly available dataset was analyzed in this study. This data can be found here: https://www.who.int/ncds/surveillance/gshs/ghanadataset/en/ (accessed on 6 October 2020).

Acknowledgments: We acknowledge the World Health Organization for making the data set for Ghana's Global School-based Student Health Survey freely accessible for our study.

Conflicts of Interest: The authors declare no conflict of interest.

\section{References}

1. Menesini, E.; Salmivalli, C. Bullying in schools: The state of knowledge and effective interventions. Psychol. Heal. Med. 2017, 22, 240-253. [CrossRef] [PubMed]

2. Neupane, T.; Pandey, A.R.; Bista, B.; Chalise, B. Correlates of bullying victimization among school adolescents in Nepal: Findings from 2015 Global School-Based Student Health Survey Nepal. PLoS ONE 2020, 15, e0237406. [CrossRef] [PubMed]

3. Peltzer, K.; Pengpid, S. Prevalence of bullying victimisation and associated factors among in-school adolescents in Mozambique. J. Psychol. Afr. 2020, 30, 64-68. [CrossRef] 
4. Arseneault, L.; Bowes, L.; Shakoor, S. Bullying victimization in youths and mental health problems: 'Much ado about nothing'? Psychol. Med. 2009, 40, 717-729. [CrossRef] [PubMed]

5. Seo, H.-J.; Jung, Y.-E.; Kim, M.-D.; Bahk, W.-M. Factors associated with bullying victimization among Korean adolescents. Neuropsychiatr. Dis. Treat. 2017, 13, 2429-2435. [CrossRef] [PubMed]

6. Olweus, D.; Limber, S.P. Bullying in school: Evaluation and dissemination of the Olweus Bullying Prevention Program. Am. J. Orthopsychiatry 2010, 80, 124-134. [CrossRef]

7. Carbone-Lopez, K.; Esbensen, F.-A.; Brick, B.T. Correlates and Consequences of Peer Victimization: Gender Differences in Direct and Indirect Forms of Bullying. Youth Violence Juv. Justice 2010, 8, 332-350. [CrossRef]

8. Kubwalo, H.W.; Muula, A.S.; Siziya, S.; Pasupulati, S.; Rudatsikira, E. Prevalence and correlates of being bullied among in-school adolescents in Malawi: Results from the 2009 Global School-Based Health Survey. Malawi Med. J. 2013, 25, 12-14.

9. Cecen-Celik, H.; Keith, S. Analyzing predictors of bullying victimization with routine activity and social bond perspectives. J. Interpers. Violence 2019, 34, 3807-3832. [CrossRef]

10. Vanderbilt, D.; Augustyn, M. The effects of bullying. Paediatr. Child Heal. 2010, 20, 315-320. [CrossRef]

11. Fogler, J.M.; Weaver, A.L.; Katusic, S.; Voigt, R.G.; Barbaresi, W.J. Recalled Experiences of Bullying and Victimization in a Longitudinal, Population-Based Birth Cohort: The Influence of ADHD and Co-Occurring Psychiatric Disorder. J. Atten. Disord. 2020, 11. [CrossRef]

12. Olweus, D. School Bullying: Development and Some Important Challenges. Annu. Rev. Clin. Psychol. 2013, 9, 751-780. [CrossRef] [PubMed]

13. Olweus, D. Bullying at school. Promot. Educ. 1994, 1, 27-31. [CrossRef]

14. Hymel, S.; Swearer, S.M. Four decades of research on school bullying: An introduction. Am. Psychol. 2015, 70, 293-299. [CrossRef] [PubMed]

15. Choi, B.; Park, S. Who Becomes a Bullying Perpetrator After the Experience of Bullying Victimization? The Moderating Role of Self-esteem. J. Youth Adolesc. 2018, 47, 2414-2423. [CrossRef] [PubMed]

16. Wu, X.; Qi, J.; Zhen, R. Bullying Victimization and Adolescents' Social Anxiety: Roles of Shame and Self-Esteem. Child Indic. Res. 2020. [CrossRef]

17. Moore, E.S.; Norman, E.R.; Suetani, S.; Thomas, H.J.; Sly, P.D.; Scott, J.G. Consequences of bullying victimization in childhood and adolescence: A systematic review and meta-analysis. World J. Psychiatry 2017, 7, 60-76. [CrossRef]

18. Sourander, A.; Gyllenberg, D.; Klomek, A.B.; Sillanmäki, L.; Ilola, A.-M.; Kumpulainen, K. Association of Bullying Behavior at 8 Years of Age and Use of Specialized Services for Psychiatric Disorders by 29 Years of Age. JAMA Psychiatry 2016, 73, 159-165. [CrossRef]

19. Acquah, E.O.; Topalli, P.-Z.; Wilson, M.L.; Junttila, N.; Niemi, P.M. Adolescent loneliness and social anxiety as predictors of bullying victimisation. Int. J. Adolesc. Youth 2016, 21, 320-331. [CrossRef]

20. Acquah, E.O.; Wilson, M.L.; Doku, D.T. Patterns and Correlates for Bullying among Young Adolescents in Ghana. Soc. Sci. 2014 3, 827-840. [CrossRef]

21. Sentenac, M.; Arnaud, C.; Gavin, A.; Molcho, M.; Nic Gabhainn, S.; Godeau, E. Peer Victimization Among School-aged Children With Chronic Conditions. Epidemiol. Rev. 2011, 34, 120-128. [CrossRef]

22. Arseneault, L. The long-term impact of bullying victimization on mental health. World Psychiatry 2017, 16, 27-28. [CrossRef]

23. Mayes, S.D.; Calhoun, S.L.; Baweja, R.; Mahr, F. Maternal Ratings of Bullying and Victimization: Differences in Frequencies between Psychiatric Diagnoses in a Large Sample of Children. Psychol. Rep. 2015, 116, 710-722. [CrossRef]

24. Twyman, K.A.; Saylor, C.F.; Saia, D.; Macias, M.M.; Taylor, L.A.; Spratt, E. Bullying and Ostracism Experiences in Children With Special Health Care Needs. J. Dev. Behav. Pediatr. 2010, 31, 1-8. [CrossRef]

25. Delprato, M.; Akyeampong, K.; Dunne, M. The impact of bullying on students' learning in Latin America: A matching approach for 15 countries. Int. J. Educ. Dev. 2017, 52, 37-57. [CrossRef]

26. Fernandes, G.; Yunes, M.A.M.; Finkler, L. The Social Networks of Adolescent Victims of Domestic Violence and Bullying. Paidéia 2020, 30. [CrossRef]

27. Akanni, O.O.; Olashore, A.A.; Osasona, S.O.; Uwadiae, E. Predictors of bullying reported by perpetrators in a sample of senior school students in Benin City, Nigeria. S. Afr. J. Psychiatry 2020, 26, 8. [CrossRef] [PubMed]

28. Wandera, S.O.; Clarke, K.; Knight, L.; Allen, E.; Walakira, E.; Namy, S.; Naker, D.; Devries, K. Violence against children perpetrated by peers: A cross-sectional school-based survey in Uganda. Child Abus. Negl. 2017, 68, 65-73. [CrossRef]

29. Arhin, D.K.; Asante, K.O.; Kugbey, N.; Oti-Boadi, M. The relationship between psychological distress and bullying victimisation among school-going adolescents in Ghana: A cross-sectional study. BMC Res. Notes 2019, 12, 1-5. [CrossRef] [PubMed]

30. Kljakovic, M.; Hunt, C. A meta-analysis of predictors of bullying and victimisation in adolescence. J. Adolesc. 2016, 49, 134-145. [CrossRef]

31. Yusuf, A.; Habibie, A.N.; Efendi, F.; Kurnia, I.D.; Kurniati, A. Prevalence and correlates of being bullied among adolescents in Indonesia: Results from the 2015 Global School-based Student Health Survey. Int. J. Adolesc. Med. Heal. 2019. [CrossRef]

32. Brewer, S.L.; Brewer, H.J.; Kulik, K.S. Bullying Victimization in Schools: Why the Whole School, Whole Community, Whole Child Model Is Essential. J. Sch. Heal. 2018, 88, 794-802. [CrossRef] [PubMed] 
33. Baiden, P.; Kuuire, V.Z.; Shrestha, N.; Tonui, B.C.; Dako-Gyeke, M.; Peters, K.K. Bullying victimization as a predictor of suicidal ideation and suicide attempt among senior high school students in Ghana: Results from the 2012 Ghana Global School-Based Health Survey. J. Sch. Violence 2019, 18, 300-317. [CrossRef]

34. Nguyen, A.J.; Bradshaw, C.; Townsend, L.; Bass, J. Prevalence and Correlates of Bullying Victimization in Four Low-Resource Countries. J. Interpers. Violence 2017, 35, 3767-3790. [CrossRef] [PubMed]

35. Owusu, A.; Hart, P.; Oliver, B.; Kang, M. The Association Between Bullying and Psychological Health Among Senior High School Students in Ghana, West Africa. J. Sch. Heal. 2011, 81, 231-238. [CrossRef]

36. Knottnerus, A.; Tugwell, P. STROBE-A checklist to STrengthen the Reporting of OBservational studies in Epidemiology. J. Clin. Epidemiology 2008, 61, 323. [CrossRef]

37. Pengpid, S.; Peltzer, K. Bullying and Its Associated Factors among School-Aged Adolescents in Thailand. Sci. World J. 2013, 2013, 1-6. [CrossRef]

38. Hazemba, A.; Siziya, S.; Muula, A.S.; Rudatsikira, E. Prevalence and correlates of being bullied among in-school adolescents in Beijing: Results from the 2003 Beijing Global School-Based Health Survey. Ann. Gen. Psychiatry 2008, 7, 6. [CrossRef]

39. Weng, X.; Chui, W.H.; Liu, L. Bullying behaviors among Macanese adolescents-Association with psychosocial variables. Int. J. Environ. Res. Public Health 2017, 14, 887. [CrossRef]

40. Khoury-Kassabri, M.; Benbenishty, R.; Astor, R.A.; Zeira, A. The Contributions of Community, Family, and School Variables to Student Victimization. Am. J. Community Psychol. 2004, 34, 187-204. [CrossRef]

41. Merrill, R.M.; Hanson, C.L. Risk and protective factors associated with being bullied on school property compared with cyberbullied. BMC Public Heal. 2016, 16, 1-10. [CrossRef] [PubMed]

42. Cluver, L.; Bowes, L.; Gardner, F. Risk and protective factors for bullying victimization among AIDS-affected and vulnerable children in South Africa. Child Abus. Negl. 2010, 34, 793-803. [CrossRef] [PubMed]

43. Vieno, A.; Gini, G.; Santinello, M. Different Forms of Bullying and Their Association to Smoking and Drinking Behavior in Italian Adolescents. J. Sch. Heal. 2011, 81, 393-399. [CrossRef] [PubMed]

44. Fleming, L.C.; Jacobsen, K.H. Bullying among middle-school students in low and middle income countries. Health Promot. Int. 2009, 25, 73-84. [CrossRef] [PubMed]

45. Maynard, B.R.; Vaughn, M.G.; Salas-Wright, C.P.; Vaughn, S.R. Bullying Victimization Among School-Aged Immigrant Youth in the United States. J. Adolesc. Heal. 2016, 58, 337-344. [CrossRef]

46. Lazarus, R.S. Coping theory and research: Past, present, and future. Psychosom. Med. 1993, 55, 234-247. [CrossRef]

47. Reed, K.P.; Nugent, W.R.; Cooper, R.L. Testing a path model of relationships between gender, age, and bullying victimization and violent behavior, substance abuse, depression, suicidal ideation, and suicide attempts in adolescents. Child. Youth Serv. Rev. 2015, 55, 128-137. [CrossRef]

48. Yen, C.-F.; Liu, T.-L.; Yang, P.; Hu, H.-F. Risk and Protective Factors of Suicidal Ideation and Attempt among Adolescents with Different Types of School Bullying Involvement. Arch. Suicide Res. 2015, 19, 435-452. [CrossRef]

49. Opperman, K.; Czyz, E.K.; Gipson, P.Y.; King, C.A. Connectedness and Perceived Burdensomeness among Adolescents at Elevated Suicide Risk: An Examination of the Interpersonal Theory of Suicidal Behavior. Arch. Suicide Res. 2015, 19, 385-400. [CrossRef]

50. Tsaousis, I. The relationship of self-esteem to bullying perpetration and peer victimization among schoolchildren and adolescents: A meta-analytic review. Aggress. Violent Behav. 2016, 31, 186-199. [CrossRef]

51. Mishna, F.; Cook, C.; Saini, M.; Wu, M.-J.; MacFadden, R. Interventions to Prevent and Reduce Cyber Abuse of Youth: A Systematic Review. Res. Soc. Work. Pr. 2010, 21, 5-14. [CrossRef]

52. Glenn, C.R.; Klonsky, E.D. A multimethod analysis of impulsivity in nonsuicidal self-injury. Pers. Disord. Theory Res. Treat. 2010, 1, 67-75. [CrossRef] [PubMed]

53. You, J.; Leung, F. The role of depressive symptoms, family invalidation and behavioral impulsivity in the occurrence and repetition of non-suicidal self-injury in Chinese adolescents: A 2-year follow-up study. J. Adolesc. 2012, 35, 389-395. [CrossRef]

54. Charles, N.E.; Ryan, S.R.; Bray, B.C.; Mathias, C.W.; Acheson, A.; Dougherty, N.M. Altered developmental trajectories for impulsivity and sensation seeking among adolescent substance users. Addict. Behav. 2016, 60, 235-241. [CrossRef]

55. Pedersen, S.L.; McCarthy, D.M. Person-environment transactions in youth drinking and driving. Psychol. Addict. Behav. 2008, 22, 340-348. [CrossRef] [PubMed]

56. Campbell, M.A. Loneliness, social anxiety and bullying victimization in young people: A literature review. Psychol. Educ. 2013, $50,1-9$.

57. Ohene, S.-A.; Johnson, K.; Atunah-Jay, S.; Owusu, A.; Borowsky, I.W. Sexual and physical violence victimization among senior high school students in Ghana: Risk and protective factors. Soc. Sci. Med. 2015, 146, 266-275. [CrossRef] 